\title{
Optimizing the Operational Conditions of a Membrane Bioreactor Used for Domestic Wastewater Treatment
}

\author{
Priscilla Zuconi Viana ${ }^{1 *}$, Ronaldo Nobrega ${ }^{1}$, Eduardo Pacheco Jordão ${ }^{2}$ and José Paulo \\ Soares de Azevedo ${ }^{3}$ \\ ${ }^{1}$ Programa de Engenharia Química; COPPE; ${ }^{2}$ Departmento de Hidráulica e Saneamento; ${ }^{3}$ Programa de \\ Engenharia Civil; COPPE; Universidade Federal do Rio de Janeiro - UFRJ; C. P. 68502; \\ zuconi@ peq.coppe.ufri.br; 21945-970; Rio de Janeiro - RJ - Brasil
}

\begin{abstract}
This study evaluated the performance of a sidestream membrane module combined with an aeration system for the treatment of municipal wastewater. To investigate the membrane's behavior and to control fouling, trials in laboratory units were conducted. In these tests, optimal values were established for some operational parameters, such as crossflow velocity, transmembrane pressure and air supply to continuously flush the membrane surface. Air supply improved the behavior of the permeate flux over time. After six hours operation, the stabilized flux was 35 $\mathrm{L} / \mathrm{m}^{2}$.h at a total pressure of 0.40 bar (wastewater pressure of 0.05 bar and air pressure of 0.35 bar) and Reynolds Number of 4,600. All permeate samples analyzed indicated absence of fecal coliform and Escherichia coli.
\end{abstract}

Key words: Membrane bioreactor, reuse, wastewater treatment, membranes

\section{INTRODUCTION}

It is estimated that currently more than one billion people face threats of insufficient water for consumption and that 25 years from now nearly 5.5 billion people will be living in areas with moderate to serious water shortages (Setti et al., 2001). Excessive local demand and degraded water quality combine in many regions to create acute problems. In the search to improve water quality and reduce demand, the use of wastewater treatment technologies to raise water quality levels so that it can be reused is fundamental. Ideally, the best-quality water can be reserved for more noble uses, such as domestic supply.

In this context, membrane bioreactors (MBR) can be an important alternative technology, consisting of biological processes in association with microfiltration or ultrafiltration membranes. The membrane module performs the function of a secondary clarifier in the conventional activated sludge process. In these systems, the membranes are able to completely retain the suspended solids due to their small pore size and to block the passage of pathogens from the wastewater to the treated effluent. The permeate obtained can be used as non-potable water.

MBRs function as advanced treatment units for removal of coliform bacteria and suspended solids that are not removed completely by the conventional activated sludge process (Yoon et al., 2004). The complete sludge retention by the membranes enables maintaining a high concentration of mixed liquor suspended solids (MLSS), which in turn permits operating the system with a low food/microorganism ratio (F/M)

\footnotetext{
* Author for correspondence
} 
and/or to reduce the aeration tank volume. Under these conditions, the use of organic material is favored, mainly for cellular maintenance, with the characteristics of the endogenous respiration phase prevailing. With a lower $\mathrm{F} / \mathrm{M}$ ratio, the biodegradation efficiency is better and the sludge production is smaller. The amount of sludge generated in these conditions is nearly $50 \%$ less than in the classic process of activated sludge through extended aeration (Choi et al., 2002).

MBRs better withstand organic load peaks and loads with a certain toxicity degree. The establishment of slow-growing and specialist microorganisms is facilitated, allowing more efficient removal of recalcitrant pollutants and high nitrification. The effluent quality is not affected by the sludge bulking, and membrane modules can be added inside aeration tanks and even in secondary clarifiers to boost the capacity of existing treatment plants.

Due to the elimination of the secondary clarifier, and sometimes of the first as well, it is possible to decrease the costs of land acquisition and civil works. This aspect is very advantageous in urban centers and housing estates, where space to build a wastewater treatment plant (WTP) is limited.

Despite the numerous benefits of MBRs, there is a major challenge to their consolidation and largescale application: the problem of fouling, which reduces the membrane's performance over time. The objective of this study was to characterize the membrane to its hydraulic permeability and investigate its behavior, seeking to improve its performance for treatment of domestic wastewater. The microfiltration membrane module was fed with activated sludge, which was recirculated. The purpose was to simulate the behavior of membranes during operation of a MBR.

In order to optimize the membrane module's performance, some operational parameters were evaluated, such as crossflow velocity in the module, transmembrane pressure and flow of air injected in the feed line (sparging). Laboratory tests were conducted to assess the quality of the resulting permeate.

\section{MATERIALS AND METHODS}

The hollow-fiber polymeric membrane was fabricated by the Membrane Separation Process Laboratory (PAM) of COPPE/UFRJ, according to the methodology proposed by Faria et al. (2002). The mean pore diameter was determined by images from a scanning electron microscope (JEOL JSM - 5300). The system used is shown in the flowchart (Fig. 1). It consisted of an aeration tank, a recirculation pump, the membrane module, a backwash pump, an air compressor and an air sparging system. The modules used were $40 \mathrm{~cm}$ long and had a membrane surface area of $0.035 \mathrm{~m}^{2}$.

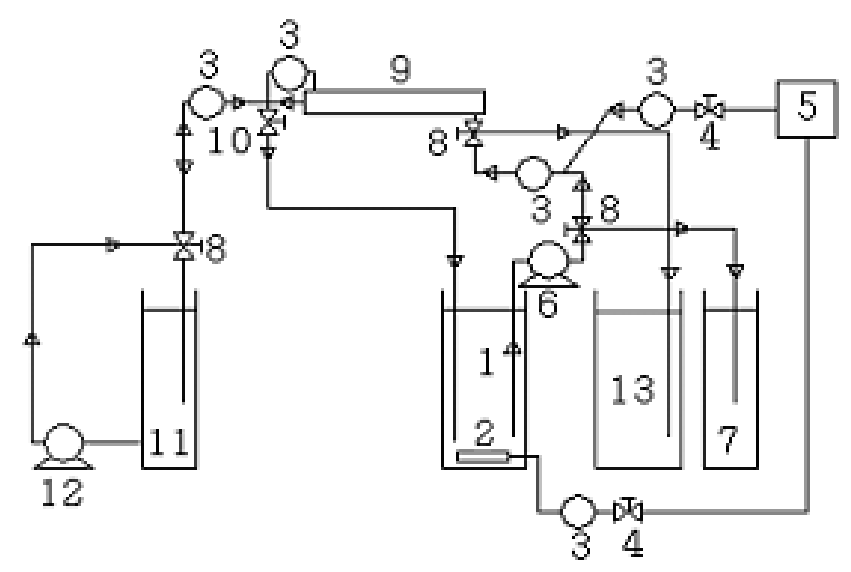

Legend: 1. Aeration tank; 2. Air diffuser; 3. Manometer; 4. Regulator valve; 5. Air compressor; 6. Positive displacement pump; 7. Influent flow measurement; 8. Three-way valve; 9. Membrane module; 10. Pressure regulator valve; 11. Permeate measurement; 12. Backwash pump; 13. Dirty water collection.

Figure 1 -Flowchart of the system assembled in the laboratory. 
This system was initially used to characterize the membranes by measuring their permeability to pure water. After characterization of water permeability, trials were conducted with activated sludge. The sludge was collected from the Penha Wastewater Treatment Plant (WTP), Rio de Janeiro. It had mean chemical oxygen demand (COD) $9,360 \mathrm{mg} / \mathrm{L}$ and total suspended solids (TSS) 6,790 mg/L. For each sample collected, analyses of COD, biochemical oxygen demand (BOD), TSS and fecal coliforms (FC) were performed. The same analyses for the permeate obtained were conducted, plus analysis of Escherichia coli. The sample analyses were done according to Standard Methods for the Examination of Water and Wastewater (1998).

\section{RESULTS AND DISCUSSION}

\section{Membrane Characterization}

From the images of the fiber obtained through the scanning electron microscope (Fig. 2 and 3), it was found that the mean membrane pore diameter was $0.64 \pm 0.37 \mu \mathrm{m}$ (expected \pm estimated standard deviation). As could be seen, the coefficient of variation was nearly 0.6 and the variance $(0.14)$ was relatively high compared to the mean pore size.

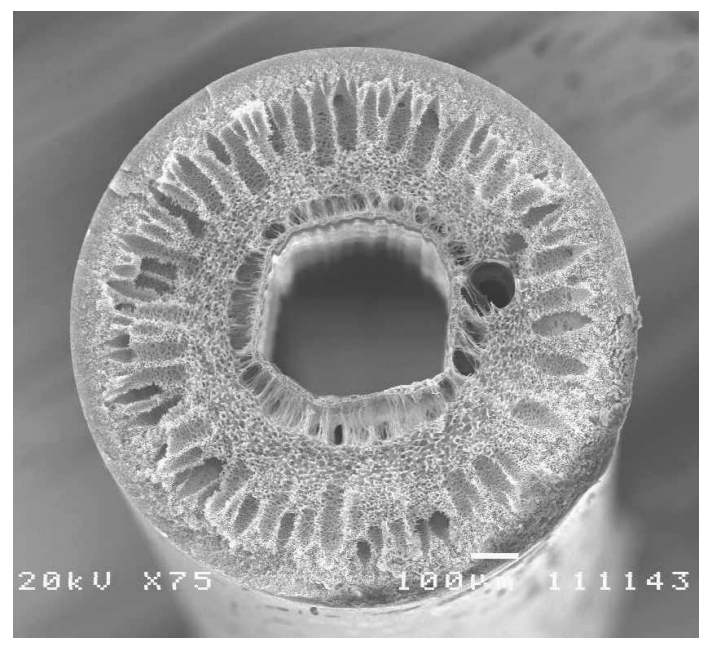

Figure 2 -Hollow fiber membrane, transversal cross-section (75x).

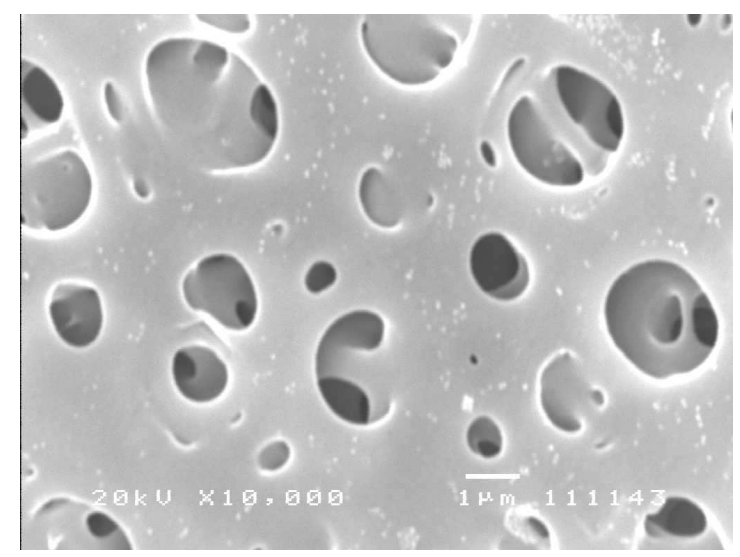

Figure 3 -Outside membrane surface, magnified 10,000x. 
This result was only an indicative value of the membrane's selectivity.The permeability to pure water, with the module outside the influent tank and the permeate retrieved by positive pressure difference, was evaluated for pressures ranging from 0.25 to 1.50 bar. Fig. 4 shows the results of these tests. It was observed that the permeate flow had a pattern of linear dependence with pressure, since there were no concentration polarization and fouling, and there were no changes in the membrane's behavior. Using these results, a regression line was fit by the least squares method. The mean membrane permeability to pure water was in the order of $900 \mathrm{~L} / \mathrm{m}^{2}$.h.bar.

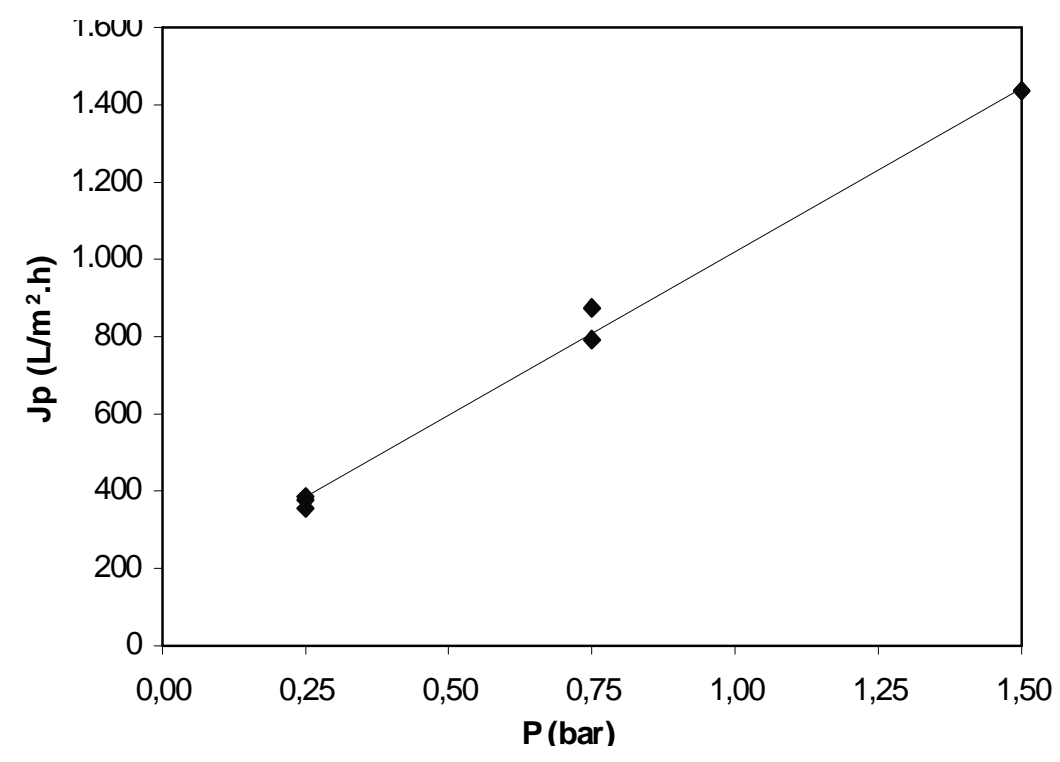

Figure 4 -Test of membrane permeability to pure water.

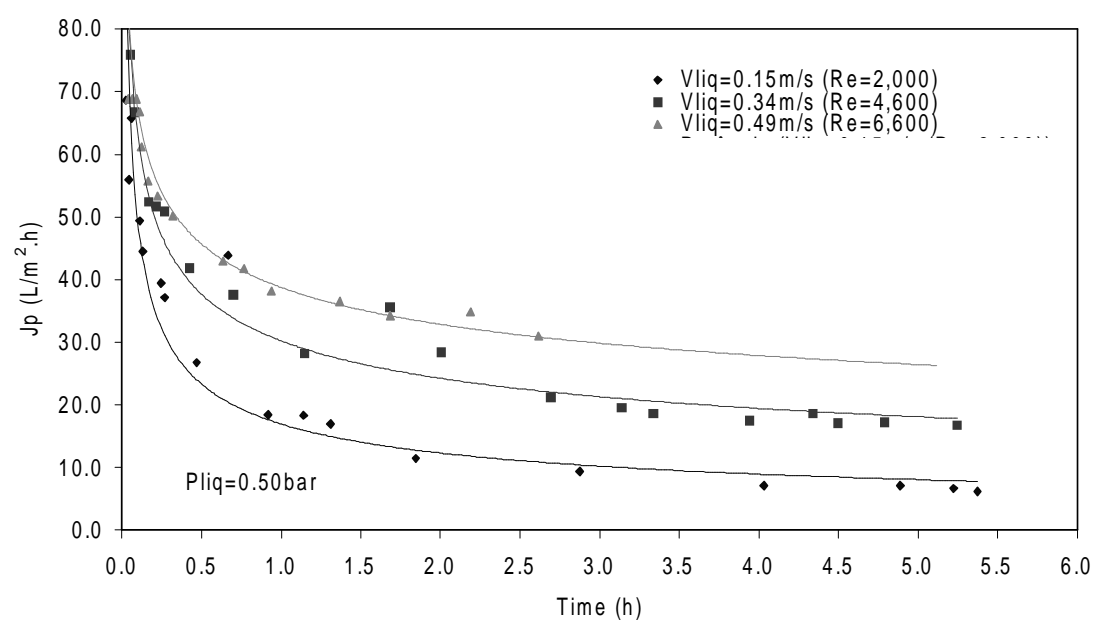

Figure 5 - Microfiltration of activated sludge -permeate flux as a function of time for a pressure of 0.50 bar and Re variation. 


\section{Trials with Activated Sludge}

In the study with activated sludge, the membrane's performance was initially evaluated over time for different influent crossflow velocities. The results are presented in Fig. 5. As could be seen, higher the Reynolds Number (Re) was, better was the behavior of the permeate flux over time for a given pressure. Thus, higher the crossflow velocity of the liquor in the module was, higher was its contribution to carrying the substances that were deposited on the membrane surface. The trials were conducted for a pressure of 0.50 bar and average MLSS concentration of 7,000 mg/L.
The system's performance for different total operational pressures (composed of the pressures generated by the sludge current and sparge air) was also assessed. The results are shown in Fig. 6. Again, higher the pressure of the injected air was, better was the permeate flow over time. The generation of larger bubbles increasing the turbulence minimized the effect of concentration of substances on the membrane surface, known as concentration polarization and of fouling. However, when the liquor circulation pressure was increased with the pressure regulator valve, the permeate flux jumped sharply but then subsided rapidly with time.

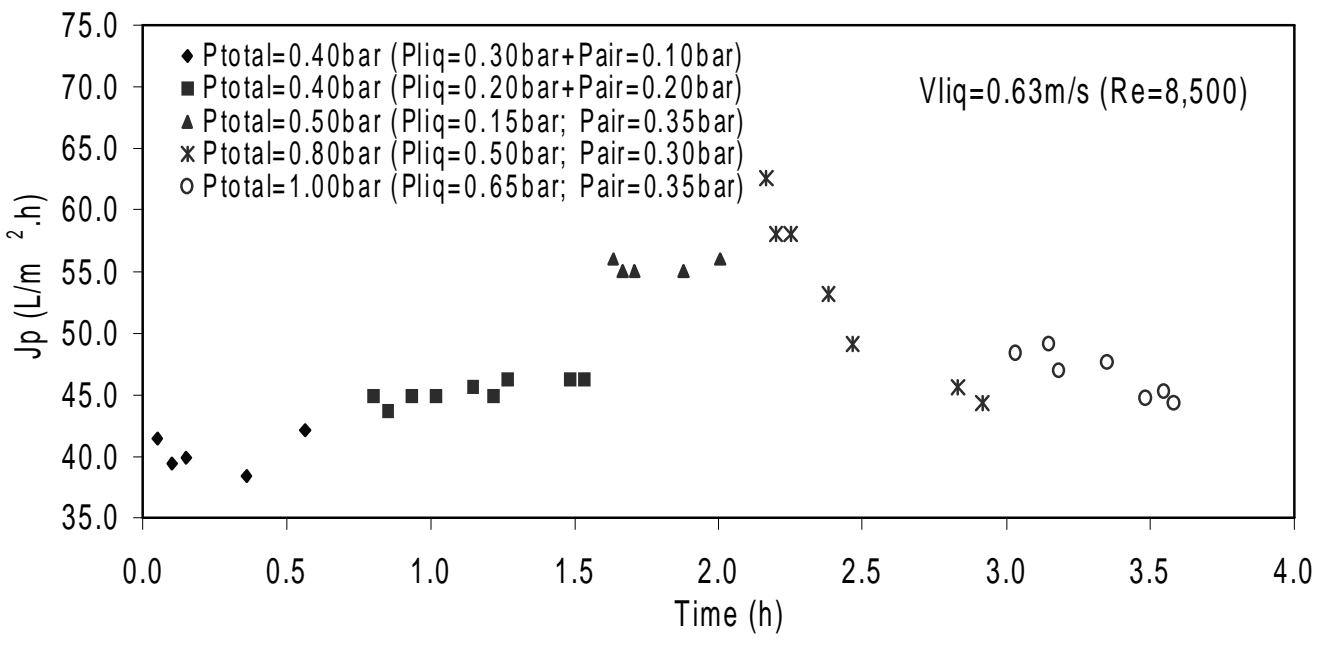

Figure 6 - Microfiltration of activated sludge -Permeate flux as a function of time. 


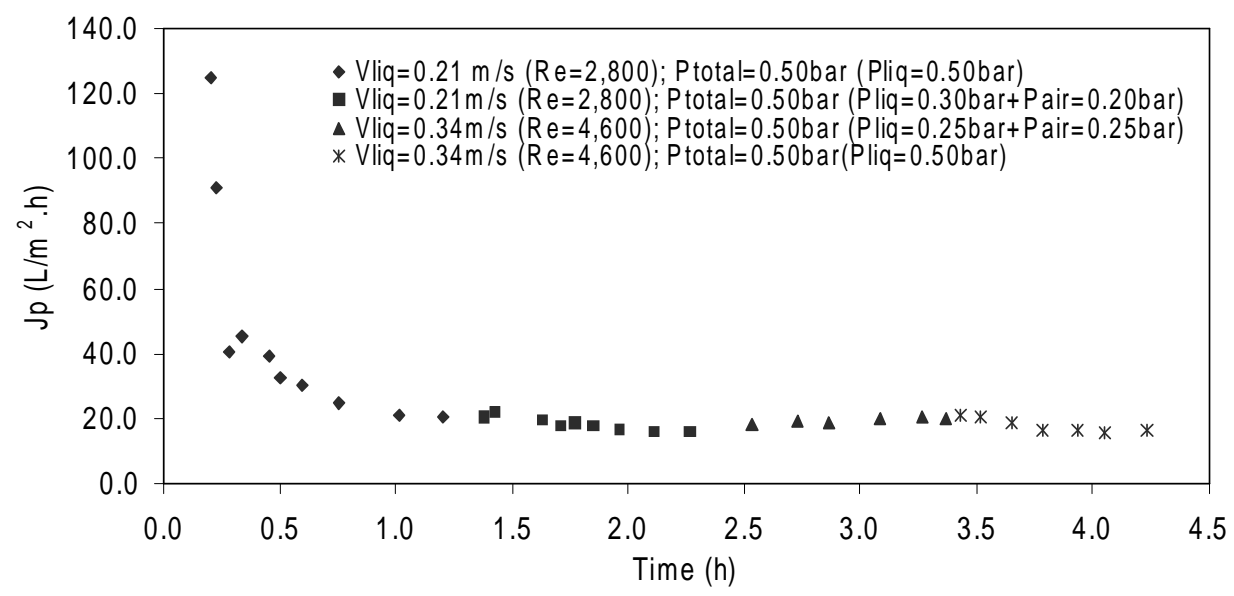

Figure 7 - Microfiltration of mixed liquor from the aeration tank with alteration of the operational parameters during testing.

This occurred because the higher pressure caused an increase in the caking on the membrane surface. Even for a quite high $\operatorname{Re}(\operatorname{Re}=8,500)$, the flow fell off quickly at a high liquor pressure, the crossflow velocity in the module and the aeration tank not being sufficient to minimize caking on the membrane surface.

To investigate the importance of the initial operational conditions on the permeate flux in established regime, an experiment starting under poor operational conditions was performed ( $\mathrm{Re}$ $=2,800$, without aeration, Pliq $=0.50$ bar) and then gradually improved these parameters. The results of these tests are shown in Fig. 7. Even with air sparging and the resulting increased crossflow velocity, it was not possible to significantly improve the permeate flux. This was probably because the effects of fouling were totally or partially irreversible, and thus even after improving the operational conditions, the flow recovery could be only partial or even negligible. Therefore, the operational parameters values of the membrane module need to be well decided since the operate beginning, because they were decisive for a good membrane performance.

A sludge concentration test was also conducted (Fig. 8) in order to assess the influence of the MLSS concentration on the permeate flux. The test was carried out by retrieving permeate at intervals without returning it. For each concentration at which the sample was collected for MLSS analysis, it was waited 15 minutes returning the permeate flux to allow the system operate for a period at the established concentration. After this period, three data on permeate flux were collected. In this test the pressure was maintained at 0.05 bar due to liquor and 0.35 bar due to air, with $\operatorname{Re}=4,600$. 


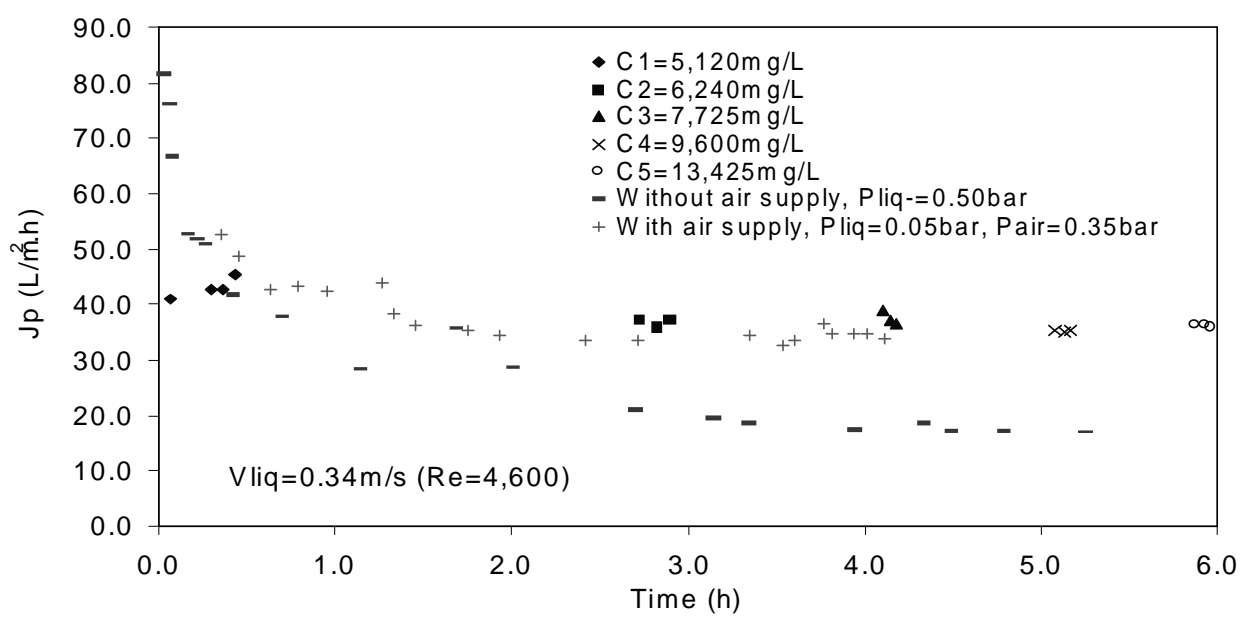

Figure 8 - Permeate flux as a function of time -sludge concentration test with $\mathrm{Re}=4,600$, Pliq=0.05 bar and Pair $\mathrm{P}=0.35$ bar.

Fig. 8 shows the results of two additional tests with $\mathrm{Re}=4,600$ and MLSS of 7,000 $\mathrm{mg} / \mathrm{L}$ : one without aeration and with liquor circulation pressure of $0.50 \mathrm{bar}$ and the other with liquor pressure of 0.05 bar and air pressure of 0.35 bar. The Reynolds Number of the tests was the same as that in the concentration test. Comparing the results of the tests, it was noted that the effect of the MLSS on the permeate flux value was virtually negligible. Probably the flux was more affected at higher concentrations. It must also be stressed that the test with liquor pressure at 0.50 bar and without aeration, the permeate flux fell considerably over time, even with the MLSS concentration held near 7,000 mg/L. Thus, it was likely that aeration minimized the fouling effect, allowing the permeate flux to stabilize more quickly regardless of the activated sludge concentration.

Regarding the efficiency of treatment, each sample collected from the Penha WTP and during the permeability tests with activated sludge was subjected to analyses for COD, BOD, TSS, FC and Escherichia coli. Table 1 presents the means of the results obtained for each parameter (four samples of activated sludge and four of permeate). The permeate always showed absence of fecal coliforms and Escherichia coli.

Table 1 - Results of the analyses of sludge and permeate .

\begin{tabular}{c|c|c}
\hline Parameter & Reactor & Permeate \\
\hline COD $(\mathrm{mg} / \mathrm{L})$ & 9,360 & 24 \\
BOD $(\mathrm{mg} / \mathrm{L})$ & 4,640 & 04 \\
TSS $(\mathrm{mg} / \mathrm{L})$ & 6,790 & $<0.5$ \\
FC (NMP/100mL) & $1,200,000$ & 0 \\
E. coli & - & 0 \\
\hline
\end{tabular}

\section{CONCLUSIONS AND SUGGESTIONS}

The results obtained indicated that the membrane performed well and was suitable for this type of application. The same module was reclaimed and reused in some tests. Better techniques of cleaning the module should be investigated to ensure its better recuperation.
Higher aeration (Pair $=0.35$ bar) allowed reducing the crossflow velocity in the module, which helped to minimize the build-up of particles (caking). It was possible to operate at high permeate flux values, even with a lower Reynolds Number (around 4,500), allowing reduced power consumption.

Regarding liquor pressure, the best long time results occurred at the minimum transmembrane 
pressure, generated only by the mixed liquor recirculation flow. However, for very low recirculation flows, it was best to ensure minimum liquor pressure by using the regulator valve. From our tests, this pressure should be held at around 0.10 bar. The flow obtained after optimizing the parameters was comparable with that obtained by many commercial MBRs.

An excellent-quality effluent was always obtained. It is proposed to operate the system continuously. The objective would be to evaluate the performance of a biological reactor and the system efficiency, besides to continue monitoring the membrane module's performance.

\section{ACKNOWLEDGMENTS}

We thank to the CNPq and FAPERJ for the Master's scholarship awarded to Priscilla Zuconi Viana.

\section{RESUMO}

Biorreatores com membrana para retenção de sólidos consistem em processos biológicos acoplados a módulos de membranas de microfiltração ou ultrafiltração. $\mathrm{O}$ presente estudo avaliou o desempenho de um módulo de membranas, combinado a um sistema de aeração, para o tratamento de esgoto doméstico. Com o objetivo de investigar o comportamento das membranas e minimizar os efeitos do "fouling", foram realizados testes em unidades em escala de laboratório, nos quais foram estabelecidos valores ótimos para alguns parâmetros operacionais, como velocidade tangencial no módulo, pressão transmembrana e vazão de ar inserida na linha de alimentação do módulo. Com a inserção de ar foi possível controlar melhor o comportamento do fluxo permeado ao longo do tempo. Após seis horas de operação, o fluxo se manteve em torno de $35 \mathrm{~L} / \mathrm{m}^{2}$.h para uma pressão total de 0,40 bar (pressão gerada pelo esgoto de 0,05 bar e pelo ar de 0,35 bar) e Reynolds de 4.600. Todas as análises das amostras do permeado indicaram ausência de coliformes termotolerantes e Escherichia coli.

\section{REFERENCES}

American Public Health Association; American Water Works Association; Water Environment Federation (1998), Standard Methods for the Examination of Water and Wastewater. American Public Health Association. 20 ${ }^{\text {th }}$ ed. Washington, DC.

Choi, J.; Bae, T.; Kimb, J.; Tak, T. and Randall, A. (2002), The behavior of membrane fouling initiation on the cross flow membrane bioreactor system. $J$. Membr. Science, 203, 103-113.

Faria, L.; Di Luccio, M.; Nobrega, R. and Borges, C. (2002), Development and characterization of microfiltration hollow-fiber modules for sterilization of fermentation media. Braz. J. Chem. Eng., 19 : (2), 141-150.

Setti, A.; Lima, J.; Chaves, A. and Pereira, I. (2001), Introdução ao gerenciamento de recursos hídricos. Agência Nacional de Energia Elétrica e Agência Nacional de Águas, Brasília/DF, Brazil.

Yoon, S.; Kim, H. and Yeom, I. (2004), The optimum operational condition of membrane bioreactor (MBR): cost estimation of aeration and sludge treatment. Water Res., 38, 37-46. 